\title{
Public Attitudes toward Climate Science and Climate Policy in Federal Systems: Canada and the United States Compared ${ }^{1}$
}

\author{
Erick Lachapelle \\ Univeristé de Montréal \\ Christopher P. Borick \\ Muhlenberg College \\ Barry Rabe \\ University of Michigan
}

\begin{abstract}
Multilevel governance poses several challenges for the politics of climate change. On the one hand, the unequal distribution of power and interests can serve as a barrier to implementing coherent policy at a federal level. On the other, these features also enable policy leadership among sub-federal units. In the context of wide variation in climate policy at both national and sub-federal levels in Canada and in the United States, this paper utilizes an original data set to examine public attitudes and perceptions toward climate science and climate change policy in two federal systems. Drawing on national and provincial/ state level data from telephone surveys administered in the United States and in Canada, the paper provides insight into where the public stands on the climate change issue in two of the most carbonintensive federal systems in the world. The paper includes the first directly comparable public opinion data on how Canadians and Americans form their opinions regarding climate matters and provides insight into the preferences of these two populations regarding climate policies at both the national and sub-federal levels. Key findings are examined in the context of growing policy experiments at the sub-federal level in both countries and limited national level progress in the adoption of climate change legislation.
\end{abstract}

KEY WORDS: climate change, public opinion, federalism, multilevel governance, carbon pricing, Canada, United States

A is the case in other complex policy areas of cross-cutting and shared jurisdiction, multilevel governance poses several challenges for the politics of climate change. Indeed, recent studies document the difficult politics of implementing coherent and effective climate policy in federal political systems (Harrison, 2007, 2012; Rabe, 2008, 2011). These difficulties include forging a national consensus in the face of disparate economic, energy, and emissions profiles among subunits, and are reflected in the cases of both Canada and the United States, where federal governments have repeatedly struggled to deliver the type of measures many policy experts say are required to avert the risks of a changing climate. At the same time, a substantial number of sub-federal jurisdictions in the two federations have taken both unilateral and cooperative action to address the issue, enacting policies ranging from emissions trading and carbon taxation to efficiency standards and renewable electricity fuel mandates and subsidies (Rabe, 2011; Selin \& VanDeveer, 2009). We argue here that a better understanding of public opinion is essential to interpreting these complex policy developments and for consideration of alternative policy trajectories moving forward. To the extent that elected officials require

Review of Policy Research, Volume 29, Number 3 (2012) 10.1111/j.1541-1338.2012.00563.x (c) 2012 by The Policy Studies Organization. All rights reserved. 
support from the public, mass opinions, perceptions, and preferences will continue to play an important role in the politics of climate change in multilevel and federalist political systems.

This paper examines the public attitudes of Canadians and Americans toward three important dimensions of the climate policy challenge. First, it explores how the publics in two of the most greenhouse gas (GHG)-intensive economies in the world perceive the issue of climate change and the reasons why they may or may not believe it is occurring. Second, the paper examines how the publics in the two federations assign responsibility to different levels of government for policy developmentwhether they support unilateral sub-federal initiatives in the absence of federal leadership or whether they expect a more active federal role in responding to climate change. Third, the paper assesses what might be learned from the various policy experiments undertaken by sub-federal jurisdictions in Canada and in the United States in terms of public acceptability of stricter carbon regulation.

To answer these questions, the paper draws on data from the most recent National Survey of American Public Opinion on Climate Change (NSAPOCC) and the National Survey of Canadian Public Opinion on Climate Change (NSCPOCC). Both administered the identical survey instrument to the Canadian and American populations at roughly the same time period. ${ }^{2}$ The data were generated from telephone surveys using random digit dialing samples in the United States and Canada, thus providing the first directly comparable public opinion data on how Canadians and Americans form their opinions regarding climate matters, and on the preferences of both populations regarding climate policies at both the federal and sub-federal levels. ${ }^{3}$ Findings based on these cross-national data contribute to the growing literature on the source of public attitudes toward climate change (Borick \& Rabe, 2010) and provide a novel look into the previously unasked question on public perception of government responsibility for climate policy in federal systems. Finally, while public acceptability is often cited as an important condition for the enactment of stricter carbon regulations (Harrison, 2012; Organization for Economic Cooperation and Development, OECD, 2006), the relationship between public opinion and the adoption of various climate policy instruments remains underexplored, particularly in a Canadian context where much less is known concerning public perceptions of climate change. This paper provides new insight into the sources of public support for various instruments of climate policy and the potential impact such support may have on policy moving forward.

The paper is divided into five sections. The first section outlines the motivation for comparing Canada and the United States in terms of public opinion on climate change and offers an overview of these two cases. Next, the paper examines views on climate change and climate science in the two countries. Third, the paper explores how the public in both federations assigns responsibility to various levels of government in addressing the climate challenge. The fourth section examines support for two of the most frequently advocated instruments of climate policyemissions trading and carbon taxes. The paper concludes with a discussion of the importance of public opinion research for understanding the politics of climate change, reflection on whether public opinion can explain sub-federal policy innovation in the absence of federal leadership, and an outline of directions for future research. 


\section{Canada and the United States Compared}

Comparison is a fundamental tool for political scientists, allowing researchers to situate their analyses in a broader context in order to reveal broad patterns and suggestive dissimilarities across cases (Collier, 1993) while also providing some means of isolating the effects of carefully selected variables on political outcomes (e.g., public policies, public opinion). Given the vast array of institutional and cultural affinities and differences between the two federations, comparing Canada and the United States has a rich history in political science (Lipset, 1990; Simeon \& Radin, 2010), as is increasingly evident in the area of comparative climate policy research (Burke \& Ferguson, 2010; Harrison, 2007; Rabe, 2007; Rabe \& Borick, 2012). While comparing the two countries has often revealed important differences, very large, undeniable, and equally important similarities exist. In particular, the two federations share a broad set of structural characteristics that make an analysis of climate change policy and attitudes toward climate policy in particular an interesting object of study. For instance, the two are among the most GHG-intensive countries in the world, both on a per capita basis (Figure 1) and in terms of the GHG intensity of their tightly linked national economies (Figure 2).

As shown in Figures 1 and 2, the United States and Canada rank among the world's most GHG-intensive economies, especially when compared with other industrialized countries in Europe, placing some (moral) responsibility on publics in these federations for climate change, given relatively high emissions per capita and level of emissions per unit of economic activity. The fact that the two countries also share one of the most tightly integrated bilateral trade relationships in the world, ${ }^{4}$ (a lack of) policies intended to reduce emissions in one country will have important policy implications in the other as will public opinion on issues related to energy policy and climate change. Given the dependence of Canada's economy on access to the U.S. market for its goods, for instance, the Canadian government's explicit policy is to wait for the U.S. Congress to enact carbon regulations in the hopes of

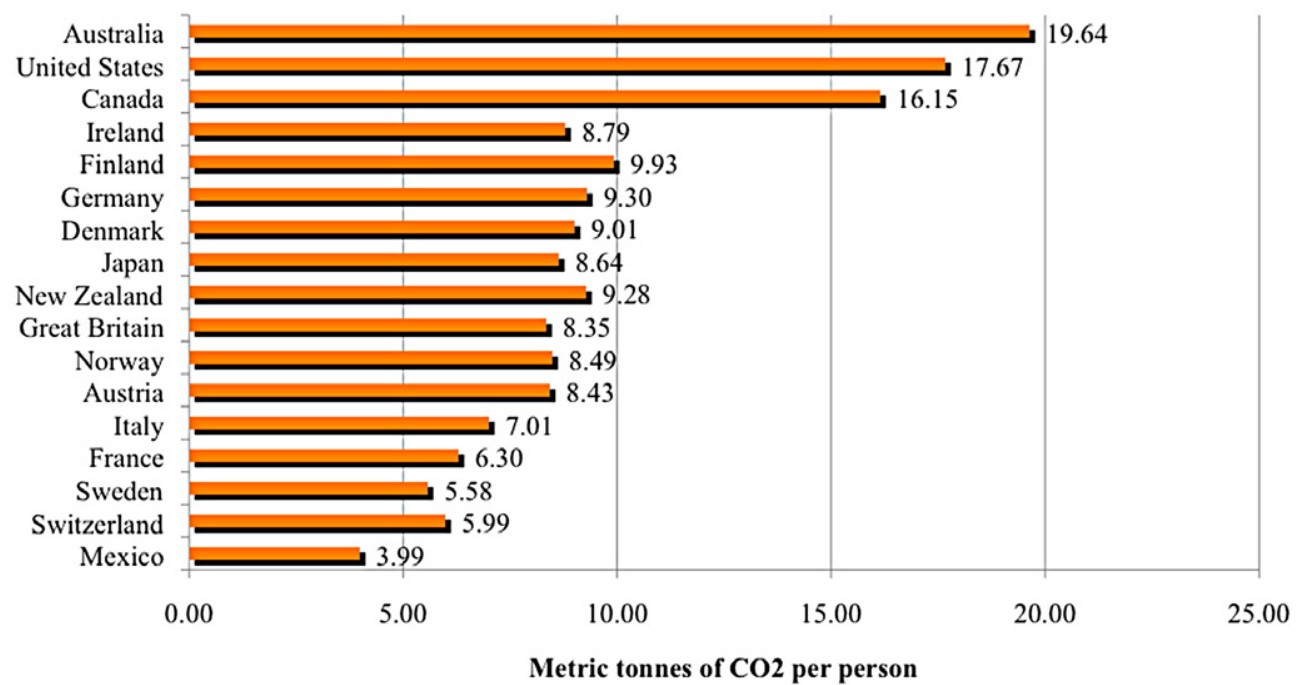

Figure 1. Carbon Dioxide Emissions per Capita in Selected OECD countries, 2009. Source: Energy Information Administration (2011) 


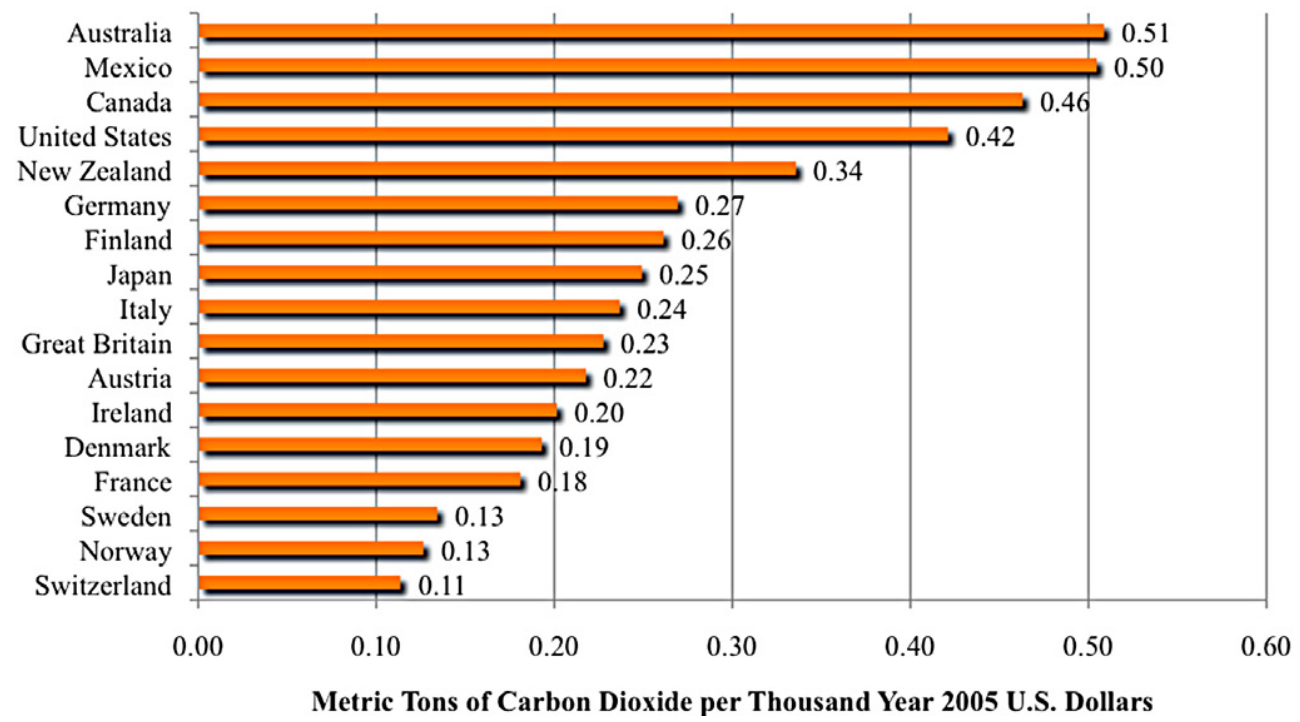

Figure 2. Carbon Intensity of Gross Domestic Product Using Market Exchange Rates, 2009. Source: Energy Information Administration (2011)

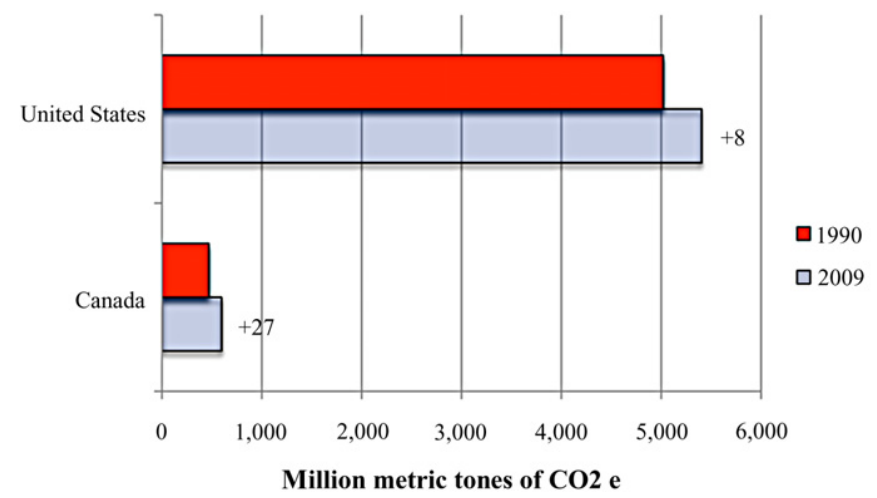

Figure 3. Energy-Related Emissions Growth in Canada and in the United States, 1990-2009. Source: Environment Canada (2009) and Energy Information Administration (2011). Note: Canadian data are for 2008 (latest available at time of publication)

harmonizing Canadian policy with its largest trading partner and the world's largest emitter of GHG (Prentice, 2009). Thus, public opinion in the United States may also impact policy developments in Canada, indirectly. In addition, the geographic contiguity and cultural proximity of the two federations provides ample opportunity for such other types of spillover as, to take one example, ideational contagion. ${ }^{5}$

Despite both Canadian and American governments having set ambitious (albeit nonbinding) emission reduction targets in the early 1990s, emissions in the neighboring federations continue to rise (Figure 3). Indeed, while annual GHG emissions from the United States dwarf those from Canada (given the relative size of its population and economy), Canadian emissions have grown at a much faster rate in recent decades. Much of this added growth has been driven by the increased development of its oil sands in part to satisfy increasing American energy demand 
(Environment Canada, 2009) and the fact that both have routinely failed to implement effective policy to mitigate annual emissions of carbon dioxide (Rabe, Lachapelle, \& Houle, unpublished data).

Several factors contribute to the GHG emission profiles and their continued growth in both countries. While the United States relies more heavily on fossil energy for the generation of electricity (International Energy Agency, 2009), the two economies host a variety of energy-intensive industries, including in the areas of steel and fossil fuel production. In addition, the two are less densely populated than other advanced economies in Europe and have more limited ground-based systems for mass transportation. This confluence of factors has resulted in a greater reliance on personal motorized vehicles to travel farther distances on average and thus more expansive use of carbon-based fuels. On the whole, Canada and the United States experienced substantial economic growth over much of the 1990s and 2000s, which further accounts for the observed increase in energy-related emissions from fuel combustion, depicted in Figure 3.

These broad characteristics shared by both countries-a geographically contiguous, culturally porous border; high emissions per capita; energy- and carbonintensive economies; relatively low population densities; and general reliance on personal motorized vehicle use for transport-might suggest that the publics in both countries would have, at a general, aggregate level, similar views based on shared interests and constraints in terms of limiting their use of fossil fuels. In this context, the following analysis explores the views of Canadians and Americans in order to empirically assess public attitudes on issues related to energy policy and climate change in both countries.

\section{Climate Change and Climate Science}

In light of their similar GHG emissions, demographic, and economic profiles, one might expect to find considerable similarities in public attitudes toward climate change policy and politics across Canada and the United States. As neighbors sharing a vast continent and common boundary, one might also anticipate similar views on the existence of climate change. However, we find considerable divergence on this issue between citizens of the two federations.

Efforts to measure American public opinion regarding global warming have been ongoing for a quarter of a century (Nisbet \& Myers, 2007). Previous polling of Americans on the existence of climate change has identified growing levels of recognition in the 2000s, subsequently followed by a sharp decline in 2009. For instance, the Pew Research Center reports that in August 2006 and January 2007, 77 percent of Americans agreed that there is solid evidence of global warming (Pew Research Center, 2009). After peaking at these levels, the same report documents a sharp decline in the percentage of Americans perceiving solid evidence that global temperatures are rising, with 71 percent of Americans maintaining this viewpoint in April 2008 and only 57 percent within this category in October 2009. These data are corroborated by findings from the NSAPOCC, which asks nearly the same question as the Pew Center, ${ }^{6}$ and documents a precipitous decline in American views on the existence of global warming from fall 2008 (72 percent) through fall 2010 (58 percent). 


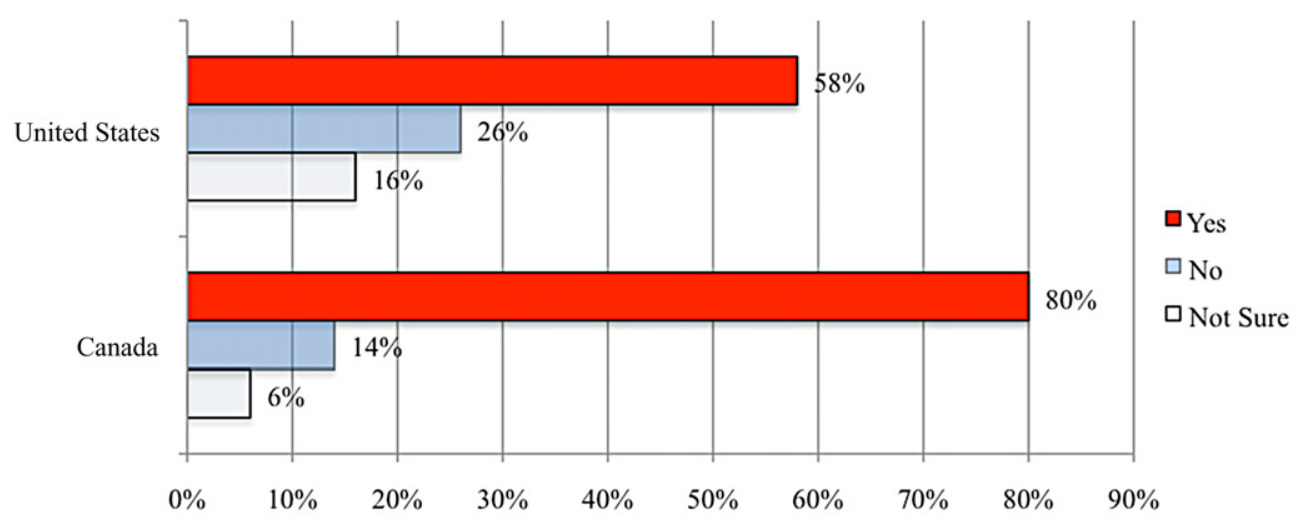

Figure 4. Perceptions on the Existence of Climate Change in Canada and the United States. Question wording: From what you have read and heard, is there solid evidence that the average temperature on Earth has been getting warmer over the past four decades?

While time series data are unavailable for Canada, the 2011 NSCPOCC asked Canadians the identical question administered in the United States. It found that four in five Canadians believed that the Earth is warming compared with about three in five Americans (Figure 4). Levels of conviction on the existence of climate change in Canada are thus currently much higher than in the United States, roughly mirroring the level of belief in the United States reported by the Pew Center in 2006 and 2007. By the same token, Americans are almost twice as likely as Canadians to state that climate change is not occurring: 26 percent of U.S. respondents stated that they perceive no solid evidence and only 14 percent of Canadians responded the same way.

This large discrepancy between Canadian and American views on the existence of global warming, however, masks important regional differences in Canada. While opinions in the United States remain relatively stable across regions, significant differences in levels of belief on the existence of climate change can be found across the Canadian provinces (Figure 5). ${ }^{7}$

Contrary to opinion in the United States, which remains relatively stable across the Northeast (59 percent), Midwest (60 percent), West (56 percent), and South (58 percent), public views on the existence of climate change vary widely in Canada, depending on the geographic location of respondents. To some extent, these differences in opinion vary along with the carbon intensity of the Canadian provinces as measured in terms of GHG emissions per capita. For instance, belief in climate change in the more greenhouse gas-intensive provinces of Saskatchewan (71 tons of $\mathrm{CO}_{2}$ per capita) and Alberta (72 tons of $\mathrm{CO}_{2}$ per capita) is significantly lower than the national average of 80 percent. $^{8}$

Despite these cross-provincial divides in Canada, the largest differences in views on the existence of global warming in both nations appear across partisan affiliation. Previous studies of opinion in the United States by Zia and Todd (2010) and McCright and Dunlap (2011) have provided evidence of a strong correlation between an individual's partisan affiliation and his or her views on climate change. Results from the NSAPOCC and NSCPOCC surveys corroborate this finding, this time in a Canadian context. Indeed, when comparing respondents across the 


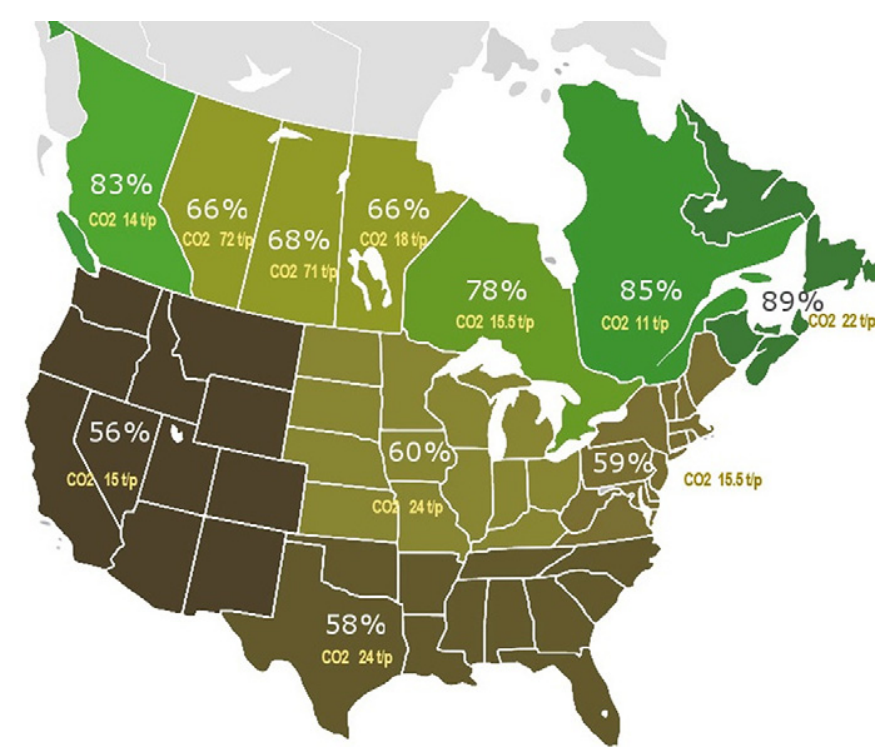

Figure 5. Perceptions on the Existence of Climate Change across Canadian Provinces and American Regions. Figure illustrating provincial and regional differences in response to the question, "From what you've read and heard, is there solid evidence that the average temperature on Earth has been getting warmer over the past four decades?"

Table 1. American Opinion on the Existence of Climate Change by Selected Demographics

\begin{tabular}{lccc}
\hline & Yes $(\%)$ & No $(\%)$ & Not Sure $(\%)$ \\
\hline Democrat & 69 & 16 & 15 \\
Republican & 41 & 43 & 17 \\
Independent & 56 & 31 & 13 \\
Tea Party member & 54 & 37 & 10 \\
Non-Tea Party member & 59 & 25 & 16 \\
Male & 53 & 30 & 18 \\
Female & 63 & 23 & 14 \\
18-29 & 62 & 28 & 10 \\
$30-44$ & 55 & 31 & 14 \\
$45-64$ & 64 & 22 & 14 \\
65 or older & 51 & 29 & 20 \\
College-educated & 64 & 25 & 11 \\
Noncollege-educated & 50 & 28 & 23 \\
Total & 58 & 26 & 16 \\
\hline
\end{tabular}

traditional socioeconomic categories commonly used in public opinion research, the largest differences emerge when comparing individuals based on their party identification. In particular, self-identified Democrats in the United States are significantly more likely than those identifying as Republicans to state they think climate change is occurring, while the views of independent voters fall almost directly in between (Table 1). Some variation in opinion is evident in other traditional demographic divides, such as gender, age, and educational attainment but is far more modest than partisan affiliation.

This pattern is repeated in Canada, where significant differences in perceptions of climate change also emerge across partisan lines. In particular, respondents identifying as supporters of Canada's Conservative Party are significantly less likely 
Table 2. Canadian Opinion on the Existence of Climate Change by Selected Demographics

\begin{tabular}{lrrr}
\hline & Yes $(\%)$ & No $(\%)$ & Not Sure $(\%)$ \\
\hline Conservative & 64 & 28 & 8 \\
Liberal & 91 & 6 & 3 \\
New Democrat & 84 & 10 & 6 \\
Bloc Québecois & 90 & 9 & $1 \%$ \\
Greens & 87 & 3 & 7 \\
Undecided & 80 & 13 & 5 \\
Male & 79 & 16 & 7 \\
Female & 80 & 12 & 4 \\
18-29 & 82 & 13 & 6 \\
30-44 & 79 & 15 & 6 \\
$45-64$ & 79 & 15 & 9 \\
65 or older & 77 & 14 & 6 \\
College-educated & 80 & 14 & 6 \\
Noncollege-educated & 78 & 16 & 6 \\
Total & 80 & 14 & \\
\hline
\end{tabular}

than supporters of all other parties to agree that average global temperatures have been warming. Indeed, self-identified Conservative Party supporters in Canada are nearly three times more likely than supporters of all other parties (including independents) to express disbelief in climate change (Table 2). There is even less variation across other traditional demographic variables than in the American case, further confirming the saliency of the partisan divide.

When examined in a comparative Canada-U.S. context, the data in Figure 5 and Table 2 indicate that despite large aggregate differences in Canadian and American views on the existence of climate change, in at least some demographic and regional categories, opinions of Canadians converge with those of the average American in general. This is particularly noteworthy in comparing Canadian opinion with that of self-identified American Democrats. One should caution, however, against inferring a clear causal relationship from these data. Indeed, it is difficult to determine whether an individual's views on climate change are determined by his or her party affiliation (i.e., because he or she is conservative and takes a cue from his or her preferred party) or whether views on climate change determine party identification (i.e., he or she supports his or her federal conservative party because of his or her shared views on the issue). Subsequent research will assess this relationship in further detail while controlling for other individual and regional predictors of belief in climate change.

Among several important lines of inquiry in public opinion research on climate change is the question of why individuals are convinced it is (or is not) occurring. Results from the most recent NSAPOCC and NSCPOCC surveys indicate some important similarities among climate change believers across Canada and the United States. For instance, the most frequently cited reasons for one's belief that global temperatures are increasing relate to individual perceptions of local climate. Interestingly, individuals in Canada and the United States are over twice as likely to cite warming temperatures and changing weather patterns in their area than any other factor taken as evidence of climate change (Figure 6).

When given an open-ended opportunity to cite the primary reason that causes an individual to believe global temperatures are increasing, most respondents who 


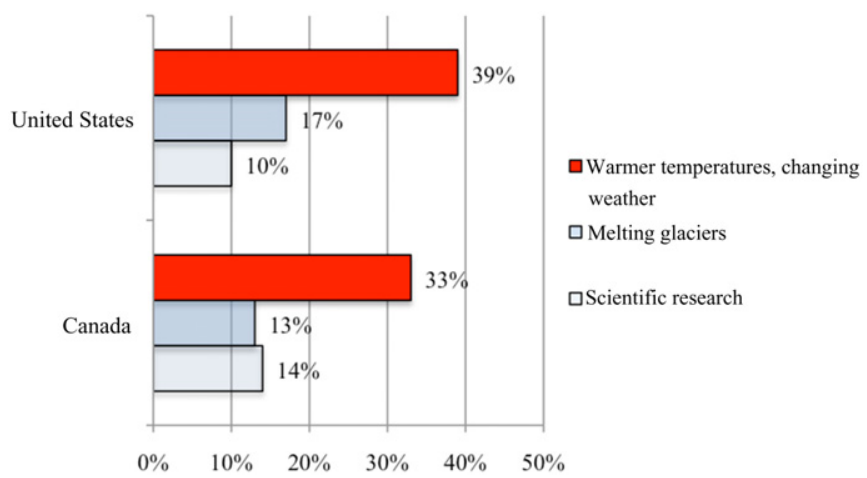

Figure 6. Most Frequently Cited Reasons for Belief in Climate Change. Question wording: And what is the primary reason that has caused you to believe that global temperatures have been increasing? (open-ended)

believe that climate change is occurring in Canada (33 percent) and the United States (39 percent) note such personal observations as perceived warming temperatures and changing weather patterns in their area. These findings partially corroborate other work highlighting the fact that "experientially derived knowledge is often more compelling and more likely to influence behaviour than is abstract knowledge" (Epstein, 1994, quoted in Leiserowitz, 2007). Canadians convinced of climate change are slightly (4 percent) less likely than Americans to cite melting glaciers and slightly more (4 percent) likely to report scientific research as their primary reason. Interestingly, Canadian men are significantly more likely than Canadian women to cite scientific evidence as a reason to believe. In total, the three response categories depicted in Figure 6 account for 60 percent of Canadian and 66 percent of American responses to the open-ended question.

One potential source of skepticism regarding the existence of climate change is the considerable media attention paid to the series of emails, leaked in early 2009 , from climate scientists that suggested their possible manipulation of data and efforts to overstate evidence of a changing climate. This overlapped with controversies surrounding some climate data analysis in prominent United Nations reports. Between 2008 and 2010, the "Climategate" scandal appears to have had some effect on the views of American respondents (Leiserowitz, Malbach, Roser-Renouf, Smith, \& Dawson, in press). For instance, data from the NSAPPCC indicate that the percentage of Americans agreeing with the statement "Scientists are overstating evidence about global warming for their own interests" spiked from 38 percent when the question was asked prior to the scandal in the fall of 2008, to 47 percent when the question was asked after the controversy in the fall of 2010 .

While data from the NSCPOCC do not allow for this type of natural experiment (since polling was first administered in early 2011), they do afford an opportunity to gain cross-national comparison with the most recent U.S. survey findings. Comparing across the two countries in 2010-11, Canadian respondents are significantly less skeptical than Americans regarding the integrity of climate science. As illustrated in Figure 7, Canadians are about 10 percent less likely to agree that scientists are overstating the case for global warming and 10 percent more likely to indicate that such accusations have no merit. To some extent, this finding is at odds with the 


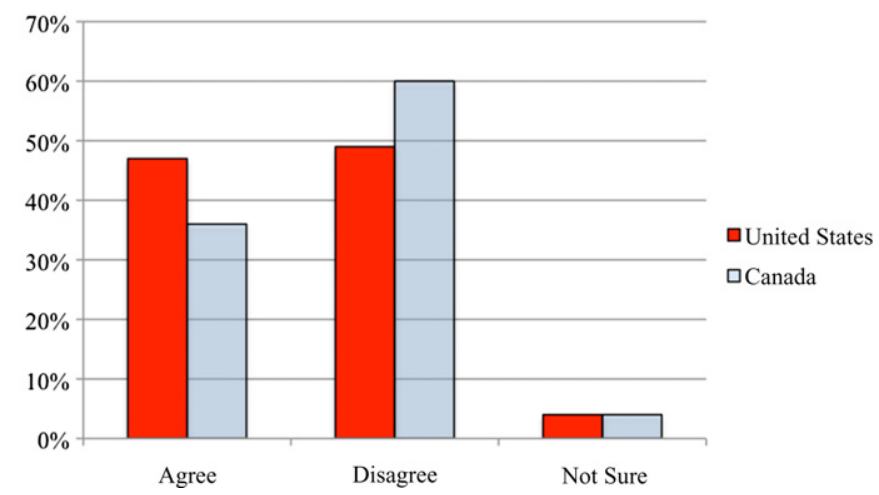

Figure 7. Canadian and American Views on the Integrity of Climate Science. Statement: Scientists are overstating evidence concerning global warming for their own interests

"decline of deference" once observed in Canadian politics (Nevitte, 1996), though more extensive data would be required to explore this question further.

While American opinion on climate science is currently divided, Canadians appear slightly more deferential toward and trusting of scientific expertise. The lack of time series data for Canada does not afford an opportunity for an assessment of Canadian views before and after the controversy over climate science. However, the difference observed between the two countries raises the question of whether differences in media coverage of the scandal may be responsible for the current divergence in attitudes among Canadians and Americans. Numerous studies in the United States suggest the media's portrayal of climate change (or new information signals) can affect opinions of Americans on this matter (Boykoff \& Boykoff, 2007; Krosnick, Holbrook, Lowe, \& Visser, 2006; Malka, Krosnick, \& Langer, 2009; Wood \& Vedlitz, 2007). Future research might test this information hypothesis to look for systematic differences in media coverage of the climate science scandal in both countries that may contribute to this difference (Liu, Lindquist, \& Vedlitz, 2011).

\section{Who Should Govern the Climate?}

In the context of failed national and international attempts at implementing effective mitigation measures, and in light of innovative practices undertaken by a number of private institutions and sub-federal jurisdictions to address the issue in the absence of a federal response, the question of "who governs the climate" has taken on considerable theoretical and practical importance (Hoffmann, 2011; Rabe, 2008). This is especially true in the multilevel Canadian and American contexts, where many states and provinces have attempted to fill the policy void left by their respective federal governments. Despite a host of ambitious commitments beginning in the early 1990s, the federal government in Canada has failed to move beyond modest spending and voluntary measures to reduce national GHG emissions levels (Rivers, 2010). Similarly, the issue of climate change has been recognized by American political leadership as far back as the 1980s, yet the prospect of Congress enacting strict federal policies on GHG emissions remains dim after reaching a high-water mark during the 111th Congress (Rabe, 2011). More 
recently, Canada withdrew from the Kyoto protocol it ratified in December 2002, joining the United States on the outside. This decision is part of a longer disagreement between the Canadian federal and provincial governments on what to do concerning climate change and contributes to the problem of growing domestic incoherence across provinces in the regulation of GHG emissions.

Both Canada and the United States can be classified as relatively decentralized federations, the constitution of each leaving considerable scope for policy innovation undertaken at multiple levels of government and at various governance scales in the areas of energy and the environment (Burke \& Ferguson, 2010). Moreover, the regional dimensions of the two geographically large federations implies that sub-federal jurisdictions wield considerable policy authority over relatively homogeneous populations, and are home to regionally concentrated industries that are characterized by distinctive GHG emission profiles and interests. When aggregated and filtered through the institutional federal framework in both countries, heterogeneous sub-federal interests have produced a policy stalemate at the federal level, while considerable scope and policy autonomy has provided a basis for policy innovation undertaken by sub-federal jurisdictions in Canada and in the United States (Rabe et al., unpublished data). Indeed, many U.S. states and Canadian provinces have taken the lead in unilaterally adopting and coordinating climate policies even in the absence of a federal role, enacting such avant-garde and diverse policies as emissions trading, carbon taxes, subsidies for renewable energy production, renewable electricity fuel mandates, and the phaseout of coal-burning power plants (Selin \& VanDeveer, 2009). Moreover, municipal governments have increasingly engaged with climate policy, further contributing to the bottom-up pattern of policy development in both federations (Gore, 2010).

To some extent, this evolution of climate policy development in Canada and the United States is at odds with the scholarly expectation that national governments would take the lead in implementing policies at the national level and in constructing a coordinated global response (Giddens, 2009; Stern, 2007). The difficulty experienced by both federal governments in developing national measures raises the question of how public perceptions accord with the current lack of federal engagement on the issue. Similarly, the climate policy leadership experienced in many U.S. states and Canadian provinces begs the question of how the public perceives the emerging patchwork of uncoordinated initiatives across American states and Canadian provinces and whether such developments are at odds with the public's assignment of roles and responsibilities of various government levels in addressing climate change. Data from the most recent NSAPOCG and NSCPOCC surveys indicate that while the Canadian and American publics place a general responsibility on the federal level, both publics indicate that national, state, and local governments all have a responsibility to address the issue of climate change (Figure 8). This portion of our analysis draws from all respondents, regardless of their views on the existence of climate change.

As might be expected given the global nature of climate change, the publics in both federations assign most responsibility to the federal government as evidenced in the majority of respondents in Canada (89 percent) and in the United States (73 percent), perceiving the federal government as having at least some responsibility for enacting mitigation policy. Interestingly, the public in Canada (88 percent) and 

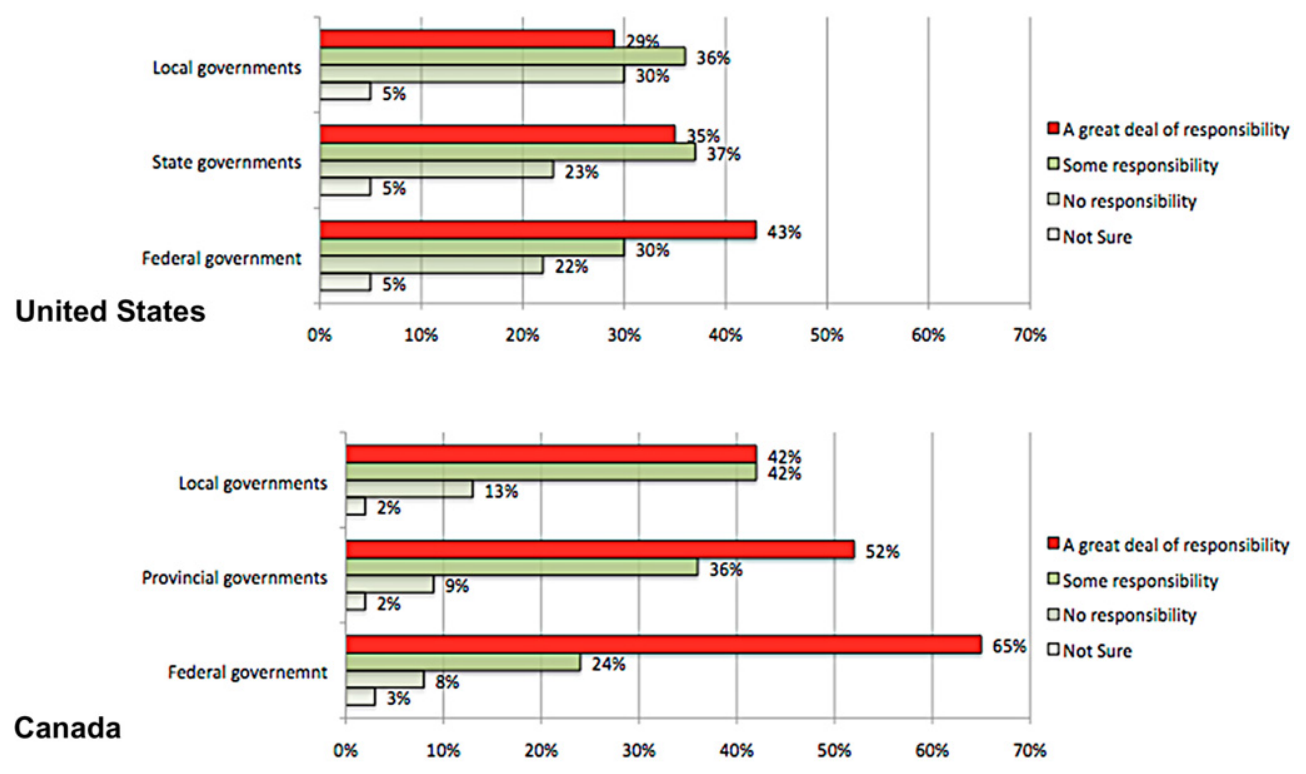

Figure 8. Public Perceptions of Government Roles and Responsibilities. Question wording: For each level of government, please tell me if it has a great deal of responsibility, some responsibility, or no responsibility for taking actions to reduce global warming

in the United States (72 percent) are generally supportive of a provincial/state role, witnessed in their views that states or provinces have either some or a great deal of responsibility to take actions to reduce global warming. More generally, the publics in Canada and the United States assign some responsibility to all levels of government, including local and municipal government, though Canadians are generally more likely to assign "a great deal of responsibility" at all governmental levels. While these views are consistent with the increased state and provincial engagement with climate policy in Canada and in the United States, public views are inconsistent with experience in both countries at the federal level, where engagement remains much more limited. In line with widely held expectations for a coordinated response, it appears as though the publics in both countries expect more from their respective federal governments than they are delivering to date.

In some respects, the absence of federal regulations on GHG emissions has left a policy vacuum for sub-federal governments to fill. In this context, one reason underlying support for policy initiatives undertaken by state and provincial governments is the lack of federal engagement on the issue (Rabe et al., unpublished data). Data from the NSAPOCC and NSCPOCC find a majority of respondents in both countries assign a duty to state and provincial governments to address global warming should their respective federal governments fail in this regard (Table 3 ).

While a majority of Americans (62 percent) and Canadians (70 percent) generally agree that their respective state and provincial governments have a duty to address global warming in the absence of federal initiatives, Canadians (37 percent) are more likely than Americans (26 percent) to strongly agree that it is the responsibility of their state/province to address the problem should their respective federal governments fail to act. Conversely, Americans are nearly twice (21 percent) as likely as Canadians (12 percent) to disagree with the same statement. 
Table 3. Provincial/State Responsibility If Federal Government Fails to Act

\begin{tabular}{lcc}
\hline & United States (\%) & Canada (\%) \\
\hline Strongly agree & 26 & 37 \\
Somewhat agree & 36 & 33 \\
Somewhat disagree & 13 & 14 \\
Strongly disagree & 21 & 12 \\
Not sure/refused & 3 & $4 \%$ \\
\hline
\end{tabular}

Statement: If the federal government fails to address the issue of global warming it is my province's/state's responsibility to address the problem.

Table 4. Opposition to Unilateral Provincial/State Policy

\begin{tabular}{lcc}
\hline & United States (\%) & Canada (\%) \\
\hline Strongly agree & 13 & 16 \\
Somewhat agree & 22 & 18 \\
Somewhat disagree & 27 & 21 \\
Strongly disagree & 32 & 41 \\
Not sure/refused & 7 & 5 \\
\hline
\end{tabular}

Statement: My province/state should not adopt antiglobal warming policies unless its neighboring provinces/states also adopt similar policies.

One potential reason why an individual may not support sub-federal initiatives relates to issues of equity and the free rider problem-a fear that one's state/ province should not unilaterally bear the burden of GHG mitigation. Interestingly, we find that the publics in both federations do not appear to follow this logic. The results of the surveys, both in Canada and in the United States, provide evidence that a majority of individuals in both federations support unilateral policy initiatives undertaken by their respective state and provincial governments (Table 4).

The survey results indicate that a majority of Americans (59 percent) and Canadians (62 percent) reject the idea that action taken by their respective state/province should be conditional upon the actions of others. Canadian respondents in particular (41 percent) are more likely than Americans (32 percent) to strongly oppose this kind of conditional support. In other words, while Canadians and Americans share similar levels of support for unilateral state and provincial policy, Canadians are more likely to indicate strong support for such leadership, independent of what neighboring jurisdictions do. This may help to explain recent policy innovations undertaken by Canadian provinces in recent years (e.g., British Columbia's broadbased carbon tax, the first of its kind in North America), which previously lagged progress in American states. Some caution in interpreting these results is warranted, however, as the negative formulation of this particular question may introduce an element of response bias in some respondents (Schuman \& Presser, 1996).

\section{Policy Preferences}

In debates surrounding the appropriate policy response to address the issue of climate change, economists have long advocated a carbon price as the most effective and efficient instrument for reducing human-made GHG emissions (Baumol \& Oates, 1985). While such market-based mechanisms as emissions taxes and cap and 


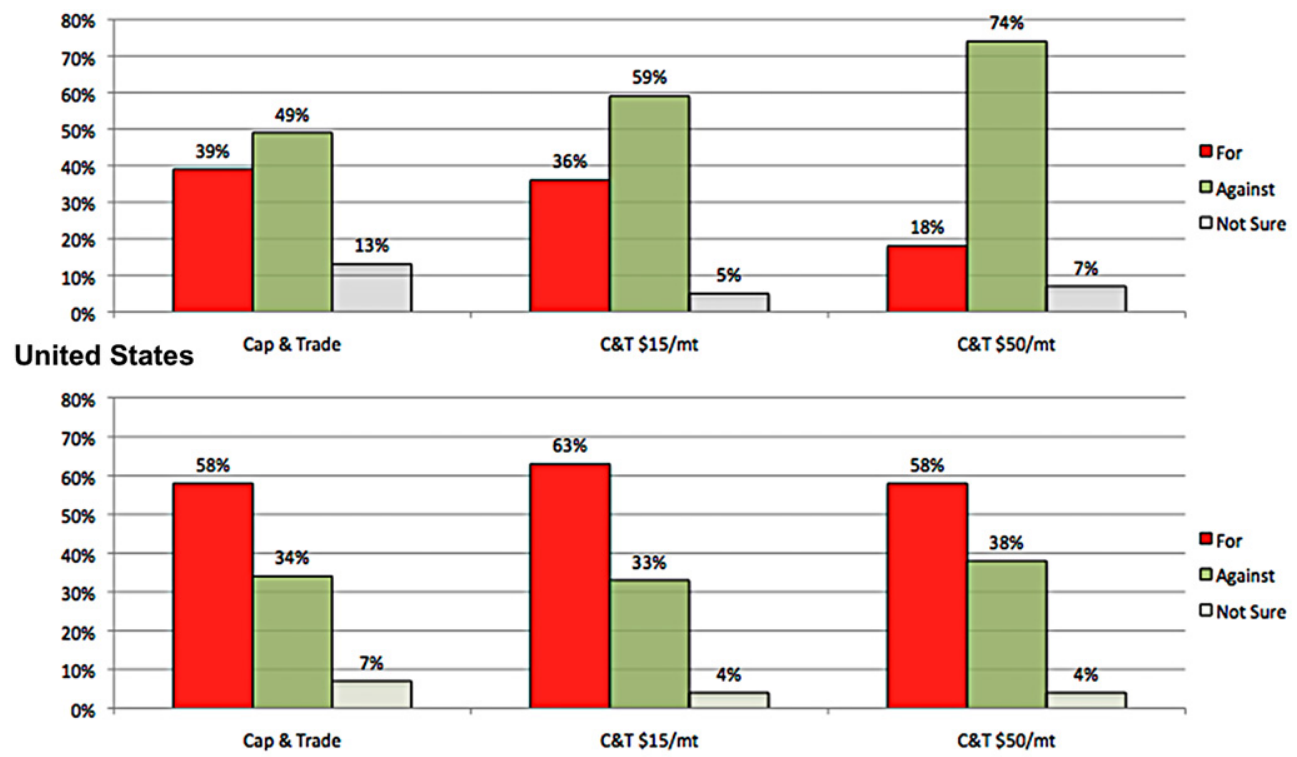

\section{Canada}

Figure 9. Support for Cap and Trade in Canada and in the United States. Question wording: There is a proposed system called cap and trade where the government would issue permits limiting the amount of greenhouse gases companies can put out. Companies that did not use all their permits could sell them to other companies. The idea is that many companies would find ways to put out less GHG because that would be cheaper than buying permits. Would you strongly support, somewhat support, somewhat oppose, or strongly oppose this type of system?

trade offer many advantages, and though widely supported by renowned economists (Mankiw, 2007) and international organizations (Jones, Keen, \& Strand, 2008; OECD, 2001), the politics of cost imposition have made their political enactment difficult. Reflected in various failed attempts to implement carbon energy taxes in the United States (e.g., Bill Clinton's failed BTU tax in 1993) and in Canada (e.g., Stéphane Dion's lost election in 2008) and in the ongoing stalemate regarding cap and trade policy in both nations, important political obstacles have prevented the national governments in both federations from moving forward with market-based instruments for climate policy (see for instance, Harrison, 2012; Rabe \& Borick, 2012).

At the same time, cap and trade continues to evolve as an important part of the policy response to climate change (Betsill \& Hoffmann, 2011), while some Canadian provinces have begun to explore the option of carbon energy taxation (Rabe \& Borick, 2012). In the North American and European contexts, previous research has highlighted the importance of public acceptability as a condition for the political success of such market instruments (Dresner, Dunne, Clinch, \& Beuermann, 2006; Harrison, 2010, 2012). The future of market-based instruments in Canada and in the United States will thus likely be shaped, at least in part, by public support for these types of policies. The latest NSAPOCC and NSCPOCC offers the possibility of assessing the feasibility of carbon price instruments in the two federations on the basis of whether there is a public demand and appetite for such measures. On the whole, opinions in Canada appear to be more accepting of cap and trade (Figure 9) and carbon tax (Figure 10) policies than in the United States. 


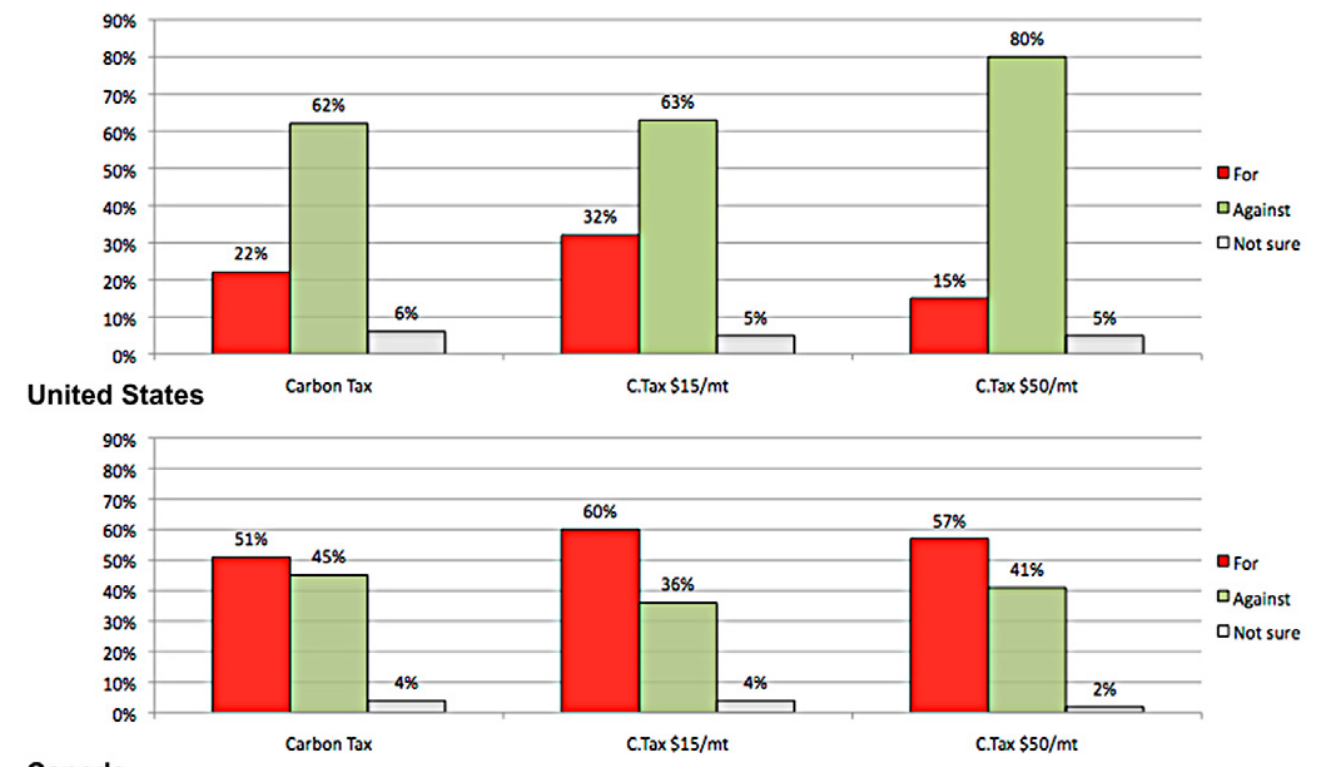

Canada

Figure 10. Support for Carbon Taxes in Canada and in the United States. Question wording: Another way to lower GHG emissions would be to increase taxes on carbon-based fuels such as coal, oil, gasoline, and natural gas. Would you strongly support, somewhat support, somewhat oppose, or strongly oppose this type of system?

While the NSCPOCC finds a majoritarian basis of support (58 percent) for a system of cap and trade in Canada, the NSAPOCC finds substantial opposition (49 percent) in the United States (Figure 9). When supporters are subsequently asked, "What if the cap and trade program significantly lowered greenhouse gases but increased your energy costs by X dollars a month?," opposition in the United States increases from 59 percent (at $\$ 15$ per month) to 74 percent (at $\$ 50$ per month) as might be expected when a financial cost is linked to a particular policy proposal (Pal \& Weaver, 2003). In Canada, support for a system of cap and trade is relatively more constant, irrespective of whether respondents are subsequently probed on associated monthly costs. Support for a system of cap and trade in Canada barely changes as respondents are told it will impose higher energy costs from $\$ 15$ per month to $\$ 50$ per month.

As is the case with cap and trade, support for carbon energy taxes is higher in Canada than in the United States (Figure 10). This is true despite the fact that Canadian voters unequivocally rejected a "green shift" (i.e., carbon tax) proposed by Liberal Party leader Stéphane Dion in the 2008 federal election (Harrison, 2012). Indeed, 51 percent of Canadian respondents support the idea of a carbon tax compared with only 22 percent of American respondents who feel the same way concerning taxing carbon. However, carbon tax opposition actually decreases, and support substantially increases among Canadian and American respondents at the level of $\$ 15$ per month. This may be taken as evidence of how little respondents understand concerning the cost implications of various climate policies and an aversion individuals have toward taxation in general, which may potentially be alleviated when they are provided information regarding the (in this case, modest) costs involved. Economic context is likely to be important as well (Scruggs \& 
Table 5. Willingness to Pay for Increased Renewable Energy Production in the United States and in Canada

\begin{tabular}{lcc}
\hline & United States $(\%)$ & Canada (\%) \\
\hline \$0 each year & 41 & 21 \\
\$1-49 each year & 26 & 28 \\
\$50-99 each year & 17 & 19 \\
\$100-249 each year & 7 & 13 \\
\$250-499 each year & 4 & 6 \\
\$500 or more a year & 2 & 7 \\
Not sure & 4 & 6 \\
\hline
\end{tabular}

Question wording: If it required you to pay extra money each year in order for more renewable energy to be produced, how much would you be willing to pay?

Benegal, in press), witnessed in the divergence between Canadian and American responses when the tax is raised from $\$ 15$ to $\$ 50$ per month. Future research on the determinants of public support for carbon taxes should pay closer attention to the potential role played by information on and sensitivity toward associated costs, as well as to prevailing economic conditions against which these costs are interpreted.

The issue of cost is central to any discussion of how to address climate change, as GHG mitigation will necessarily require changes for businesses and consumers accustomed to their GHG-producing behavior. Given the relatively high GHG intensity of the American and Canadian economies, mitigation policies designed to deter the use of fossil fuels will have important implications for the use of carbon energy sources predominant in the United States and in Canada. In this light, a greater willingness to pay on behalf of Canadians relative to Americans may partially explain the higher levels of support found for carbon taxes and cap and trade in Canada (Table 5).

The Canadian and American public somewhat diverge on their willingness to pay for the development of renewable energy sources. In particular, Americans are nearly twice as likely (41 percent) as Canadians (21 percent) to indicate that they are not willing to bear any additional yearly cost for the development of more renewable energy. Although Canadians are slightly more likely to express a willingness to pay more for increasing the availability of alternative fuels, the differences are not substantial. Interestingly, when these data are examined in an historical context, the differences found in the most recent NSAPOCC and NSCPOCC surveys largely disappear. Historically, willingness to pay levels in the United States was substantially higher in 2008 and 2009, corresponding to a relatively more favorable economic climate in the United States at that time.

Beyond the public's willingness to pay, the framing and design of policies may also shape public views and acceptance of particular instruments (Pralle \& Boscarino, 2011). Such design features as revenue neutrality and earmarking can have important implications for public acceptability (Dresner et al., 2006). Moreover, the question of which level of government should be responsible for collecting revenues, and whether and how the revenue should be shared across regions, has led to some controversy in both nations. Data from the NSAPOCC and the NSCPOCC provide some insight into where the public stands on both the question of revenue use (Figure 11) and revenue collection (Figure 12). 


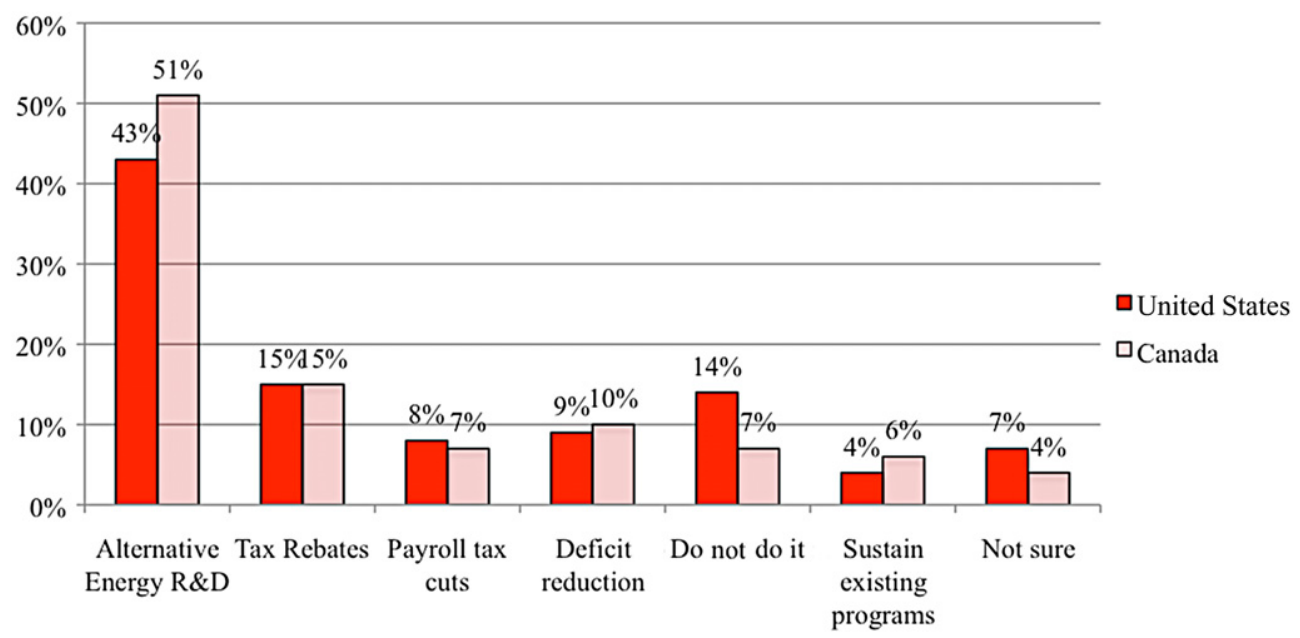

Figure 11. Views on Revenue Use from Carbon Price Policy in Canada and the United States. Question wording: If the government enacted a policy that required business to pay for the release of greenhouse gases, where do you prefer the money generated be spent?

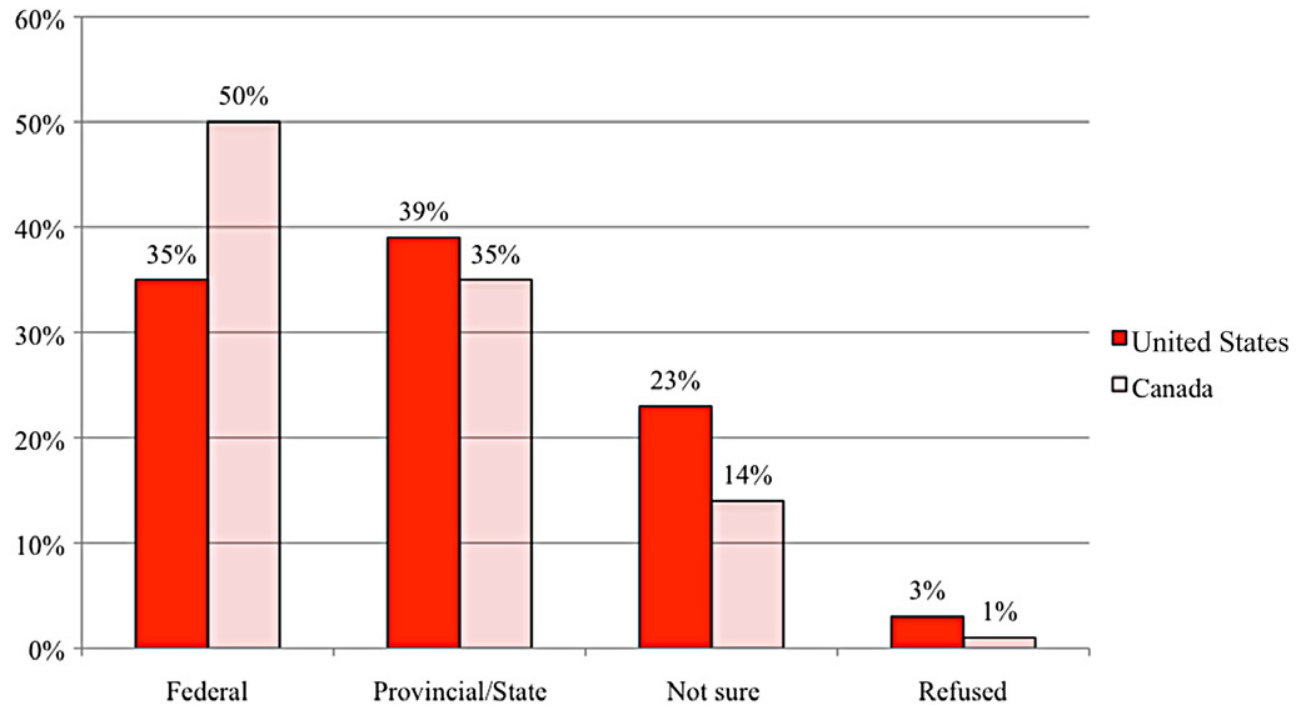

Figure 12. Views on Revenue Collection and Use from Carbon Price Policy in Canada and the United States. Question wording: And which level of government should collect and use the revenue?

Public attitudes toward revenue use in Canada and in the United States are strikingly similar and challenge a common view that carbon taxes should be revenue neutral in order to mitigate public concerns of a government cash grab. For instance, in both Canada (51 percent) and in the United States (43 percent), the public expresses a clear preference for earmarking carbon price revenues to the funding of alternative and renewable energy when given a wide range of options. This finding resonates with existing tax policy experience, where governments have legitimated unpopular policies such as gasoline taxes by earmarking revenues to finance road construction and maintenance, as well as with empirical studies of political acceptability in Europe (Dresner et al., 2006). On the other hand, relatively 
few Canadians and Americans prefer that the money be recycled through rebates, payments, and tax cuts, which, ironically, is the way most carbon tax jurisdictions allocate their revenue (Lachapelle, 2010). As shown reading across Figure 11, once revenue use options are presented, there is also surprisingly low appetite to repeal the proposed cost imposition policy (i.e., "don't do it"), should such a policy be implemented.

In contrast to the clear preferences on the issue of revenue use, the Canadian and American publics are much more divided on which level of government should collect and spend revenues from carbon pricing policy. While 50 percent of Canadian respondents prefer that the money be collected and used by the federal government, a sizeable minority (35 percent) prefers that the revenues remain within their respective province. In the United States, opinions are more sharply divided, with 35 percent preferring the money accrue to the federal government and 39 percent preferring that the revenues remain the prerogative of their home state. These national aggregates likely mask important regional differences, which will be analyzed in future work.

\section{Discussion}

The data examined in this paper represent one of the first efforts to formally compare public attitudes on climate change and related policy options between Canada and the United States using an identical, comprehensive climate survey instrument administered at roughly the same time. The findings suggest that despite many similarities in terms of emissions growth, per capita emissions, difficulty in coordinating policy at the federal level, and more recent federal disengagement with the issue, public opinion in the two federations often diverges, sometimes quite remarkably. For instance, broadly speaking, there appears to be a greater appetite in Canada for aggressive climate policy, though we also note a more favorable economic climate existed in Canada at the time of polling. When analyzed in a historical perspective, it is clear that public opinion on climate change matters is relatively elastic, evolving over time in concert with short-term weather events (Krosnick et al., 2006), prevailing economic conditions (Scruggs \& Benegal, in press), as well as with changing legal frameworks governing climate change. Indeed, as 2011 drew to a close, surveys in the United States had found a rebound in public acceptance of global warming, with more Americans linking climate change to extreme weather events while also discounting economic conditions as a reason for forgoing efforts to address climate change (Leiserowitz, Maibach, RoserRenouf, Smith, \& Hmielowski, 2011). While future work will test the relative strength of various influences on public opinion using data from the NSAPOCC and NSCPOCC surveys, we offer some exploratory remarks here.

Empirically, the foregoing analysis points to an emerging gap between what the Canadian and American publics expect from their respective federal governments, on the one hand, and the current level of engagement by these governments in the area of climate change, on the other.

This disconnect between opinion and policy may be the product of many factors, including the relatively low priority that citizens, at least in the United States, place on climate change, particularly during a protracted economic recession that has 
been more severe in the United States than Canada (Pew Research Center, 2010; Scruggs \& Benegal, in press). Conversely, it may also be the case that opinion responds in accordance with varying levels of policy leadership mobilized at different levels. Indeed, our analysis finds broad public support for local policy action taken by municipal, provincial, and state governments in Canada and in the United States, which aligns with recent policy developments in recent years. We also identify potential framing issues for governments moving forward with carbon pricing policy and note in particular the role of information cues and a preference for earmarking revenues. These findings add new dimensions to the challenge of coordinating coherent climate policy in multilevel systems, as the public seems relatively uninformed concerning the cost implications of various policy options, yet expect all levels to play at least some role in devising a solution to the problem.

A key theoretical question raised by public opinion research is whether public opinion matters for policy. While it is clear public opinion should matter in such representative democracies as Canada and the United States, the relationship between public opinion and policy outputs is complex. Political preferences are mediated by a host of such domestic institutions as the electoral system, regionalism, and federalism, which can complicate the translation of the popular will into actual policy. Working the other way, opinions themselves may be influenced by the implementation and expected effects of different climate policies.

The NSAPOCC and NSCPOCC surveys provide some scope for exploring the nature of the public opinion-public policy nexus. For instance, the historical time series of public opinion in the United States points to a peak in public concern over climate change in 2008, corresponding to the 2009 Congressional surge to forge a national climate policy at the federal level. Whether the subsequent drop in levels of belief in global warming is partially responsible for the more recent federal retreat from climate policy remains an open question. ${ }^{9}$ Conversely, the rise of state and provincial engagement with climate change corresponds to relatively high levels of public support for actions taken at this level, even in the absence of federal leadership and even if neighboring states and provinces fail to implement similar policy.

Both the NSAPOCC and the NSCPOCG afford some way to assess whether public opinion might explain why a number of local, state, and provincial governments have experimented with innovative climate policy in light of the policy vacuum created by inaction at the federal level. To take one example from the 2011 NSCPOCC, support for carbon tax policy is highest in the two provinces that have implemented carbon taxes (British Columbia and Quebec), highlighted in darker shade (Figure 13).

As shown in Figure 13, support for carbon taxation is highest in the two provinces that have successfully implemented a carbon tax. ${ }^{10}$ The case of carbon energy taxation is illustrative in that carbon taxes are consistently the least supported policy instrument by the public yet are often endorsed as the best policy option by climate policy experts. If public opinion plays a role in government decisions on climate change policy, it is thus likely to play its most important role in the area of carbon energy taxation. While other factors are likely at play, the fact that greater public support is found in the two provinces that passed carbon tax legislation suggests that opinion may facilitate the implementation of such policies. The same pattern is 


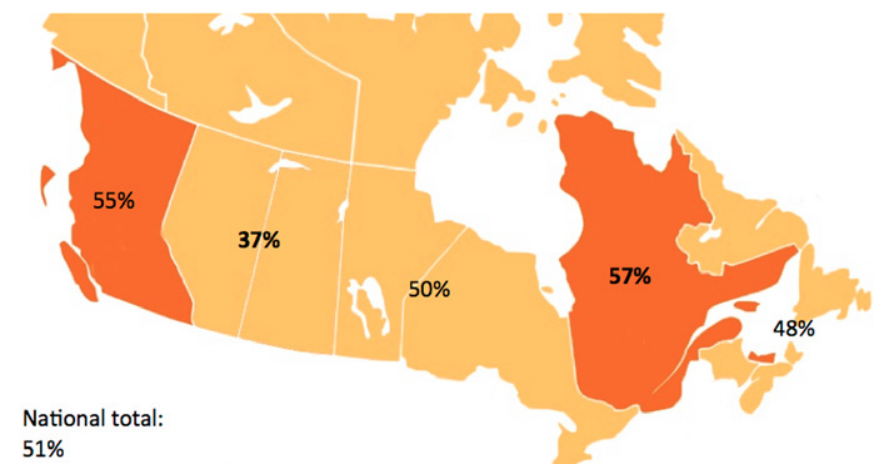

Figure 13. Support for Carbon Taxes across Canadian Regions. Figure illustrates the percentage of respondents expressing moderate to strong support for carbon taxation. Question wording: Another way to lower GHG emissions would be to increase taxes on carbon-based fuels such as coal, oil, gasoline, and natural gas. Would you strongly support, somewhat support, somewhat oppose, or strongly oppose this type of system?

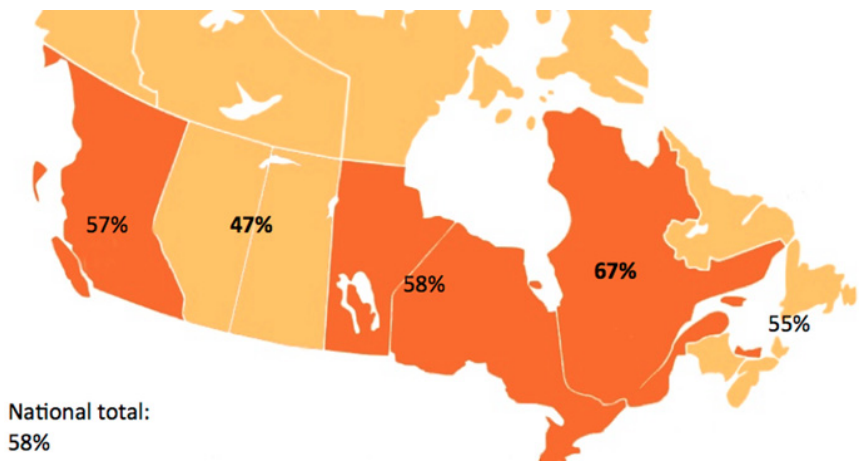

Figure 14. Support for Cap and Trade across Canadian Regions. Figure illustrates the percentage of respondents expressing moderate to strong support for a system of cap and trade. Question wording: There is a proposed system called cap and trade where the government would issue permits limiting the amount of greenhouse gases companies can put out. Companies that did not use all their permits could sell them to other companies. The idea is that many companies would find ways to put out less GHG because that would be cheaper than buying permits. Would you strongly support, somewhat support, somewhat oppose, or strongly oppose this type of system?

found when looking at support for the idea of cap and trade, which is highest in those provinces currently involved in setting up the Western Climate Initiative (WCI) (Figure 14).

As Figure 14 illustrates, support for a system of cap and trade is highest in the provinces that are active in negotiations around the WCI. The Canadian provinces of British Columbia, Manitoba, Ontario, and Quebec are all members of the WCI and have participated in the preparation of the initiative, which would create the largest carbon market in North America. While the data do not allow for direct causal inference, they are suggestive. At the very least, they are indicative of the fact that public opposition does not increase with experience developing and implementing these types of policies.

In this paper, we have argued that a better understanding of public opinion in the areas of energy policy and climate change is important, especially in such GHG-intensive, geographically, and culturally proximate countries as Canada and the United States. To the extent that responding to climate change will impose costs 
on the public, concern for the risks involved, and overall support for various measures will facilitate their implementation. As elected officials decide on the future of climate policy at all levels, a better understanding of factors underlying support for these instruments is thus fundamental. To be sure, we do not claim that the influence of opinion on policy is direct and determinate. Indeed, Canada's recent federal disengagement with Kyoto occurred at a time where polls document high levels of concern and support for an international treaty (Environics, 2011). However, opinion levels must be interpreted within the institutional structures (e.g., federalism, the electoral system), which mediate their influence on elected officials.

The analysis here thus adds a new dimension to the complex politics of governing the climate in multilevel systems and points to new areas of fruitful research. Comparing within and across federal systems is one area that may allow for an increased ability to control for the effects of various institutional variables, while probing the effects of local weather patterns, slight differences in economic fluctuations, and cross-border effects. Future research should build on these early findings of the NSAPOCC and the NSCPOCC to develop a better understanding of such factors underlying public support as changing economic conditions, personal observations of the climate, new information, public trust, and political ideology at individual and regional levels of analysis. These findings might then be used to better understand the complex, potentially bidirectional relationship between public opinion and public policy as mediated by various political institutions and may help identify important conditions for policy change. Comparison between these neighboring North American federations and other multilevel governmental systems is therefore a promising arena for future research.

\section{Notes}

1 We thank the Center for Local, State, and Urban Policy, the Gerald R. Ford School of Public Policy, the University of Michigan, the Muhlenberg College Institute of Public Opinion, the Public Policy Forum, and Sustainable Prosperity for funding. We also thank participants at the "Environmental Policy in Federal Systems" panel organized by the Federalism and Intergovernmental Relations section of the American Political Science Association in Seattle, 2011. Finally, we thank the anonymous reviewers and editor of this journal for constructive comments and helpful suggestions.

2 November 15 to December 9, 2010 in the United States, and January 13 to February 4, 2011 in Canada. Funding was provided by the Muhlenberg Institute of Public Opinion at Muhlenberg College, the Public Policy Forum, Sustainable Prosperity, Internat Energy Solutions Canada, and the Center for Local, State, and Urban Policy at the Gerald Ford School of Public Policy at the University of Michigan.

3 The U.S. sample includes both cellular telephones and landlines, while the Canadian sample is drawn from landlines only.

4 Canada and the United States are each other's largest trading partners. In 2009, 73 percent of Canadian exports were destined for the American market, with 63 percent of total Canadian imports originating from the United States (Statistics Canada, 2011). While trade with Canada represents a substantially smaller proportion of total U.S. bilateral trade (23 percent of total exports and 17 percent of total imports), the United States trades more with Canada than with all European Union countries combined (U.S. Census Bureau, 2011). Canada is also the largest foreign supplier of energy for the U.S. market.

5 Through, for instance, Canadian consumption of U.S. mass media sources. We thank one of the paper reviewers for raising this point.

6 The Pew Center does not use a four-decade time frame but instead reads "recent decades." 
7 Regional groupings in the United States were created to increase the sample size of geographic units and follow standard U.S. Census Bureau regional designations. While this regional classification likely masks important cross-state differences, the procedure allows for some cross-regional comparison to be made.

8 At a 95 percent confidence interval.

9 As suggested by Scruggs and Benegal (in press), fluctuations in the economic cycle may also play a role here, explaining at once federal disengagement and a decline in public belief.

10 Regional groupings in Canada (shown in Figures 13 and 14) were created in order to ensure a sample size of at least 100 respondents. Paired jurisdictions share broadly similar emissions profiles.

\section{About the Authors}

Erick Lachapelle is an Assistant Professor at the Université de Montréal.

Christopher P. Borick is Associate Professor of Political Science and Director of the Muhlenberg Institute of Public Opinion, Muhlenberg College.

Barry Rabe is the J. Ira and Nicki Harris Family Chair of Public Policy and the Arthur F. Thurnau Professor of Environmental Policy at the Gerald R. Ford School of Public Policy, University of Michigan. He is the director of the Center for Local, State, and Urban Policy at the Ford School.

\section{References}

Baumol, W., \& Oates, W. (1985). The theory of environmental policy. Englewood Cliffs, NJ: Prentice-Hall.

Betsill, M., \& Hoffmann, M. (2011). The contours of "cap and trade": The evolution of emissions trading systems for greenhouse gases. Review of Policy Research, 28(1), 83-106.

Borick, C. P., \& Rabe, B. G. (2010). A reason to believe: Examining the factors that determine individual views on global warming. Social Science Quarterly, 91(3), 777-800.

Boykoff, M. T., \& Boykoff, J. M. (2007). Climate change and journalistic norms: A case-study of US mass-media coverage. Geoforum, 38, 1190-1204.

Burke, B., \& Ferguson, M. (2010). Going alone or moving together: Canadian and American middle tier strategies on climate change Publius, 40(3), 436-459.

Collier, D. (1993). The comparative method. In A. W. Finifiter (Ed.), Political science: The state of the discipline II (pp. 105-119). Washington, DC: American Political Science Association.

Dresner, S., Dunne, L., Clinch, P., \& Beuermann, C. (2006). Social and political responses to ecological tax reform in Europe: An introduction to the special issue. Energy Policy, 34(8), 895-904.

Energy Information Administration (EIA). (2011). International energy statistics. Retrieved from http:// www.eia.gov/cfapps/ipdbproject/IEDIndex3.cfm

Environics. (2011). Canadians continue to voice strong support for actions to address climate change, including an international treaty and carbon taxes. December 1, 2011. Retrieved from http://www.environics.ca/referencelibrary

Environment Canada. (2009). National inventory report 1990-2008. Greenhouse gas sources and sinks in Canada. Ottawa, ON: Environment Canada.

Epstein, S. (1994). "Integration of the cognitive and the psychodynamic unconscious". American Psychologist, 49(8), 709-724.

Giddens, A. (2009). The politics of climate change. Cambridge, MA: Polity.

Gore, C. D. (2010). The limits and opportunities of networks: Municipalities and Canadian climate change policy. Review of Policy Research, 27(1), 27-46.

Harrison, K. (2007). The road not taken: Climate change policy in Canada and the United States. Global Environmental Politics, 7(4), 92-117.

Harrison, K. (2010). The comparative politics of carbon taxation. Annual Review of Law and Social Science, 6 , 507-529.

Harrison, K. (2012). A tale of two taxes: The fate of environmental tax reform in Canada. Review of Policy Research, 29(3), 385-409.

Hoffmann, M. (2011). Climate governance at the crossroad: Experimenting with a global response after Kyoto. New York, NY: Oxford University Press.

International Energy Agency (IEA). (2009). $\mathrm{CO}_{2}$ emissions from fuel combustion. Paris: OECD. 
Jones, B., Keen, M., \& Strand, J. (2008). Paying for climate change: Finance and development. Washington, DC: IMF.

Krosnick, J., Holbrook, A., Lowe, L., \& Visser, P. (2006). The origins and consequences of democratic citizens' policy agendas: A study of popular concern about global warming Climatic Change, 77, 7-43.

Lachapelle, E. (2010). Following the doctor's orders: Carbon tax theory and practice in the OECD. Paper presented at the ISA Annual Convention, New Orleans, LA.

Leiserowitz, A. (2007). Climate change risk perception and policy preferences: The role of affect, imagery, and values. Climatic Change, 77, 45-72.

Leiserowitz, A., Malbach, E. W., Roser-Renouf, C., Smith, N., \& Dawson, E. (in press). Climategate, public opinion, and the loss of trust. To appear in American Behavioral Scientist.

Leiserowitz, A., Maibach, E., Roser-Renouf, C., Smith, N., \& Hmielowski, J. D. (2011). Climate change in the American mind: Americans' global warming beliefs and attitudes in November 2011. Yale University and George Mason University. New Haven, CT: Yale Project on Climate Change Communication. Retrieved from http://environment.yale.edu/climate/files/ClimateBeliefsNovember2011.pdf

Lipset, S. M. (1990). Continental divide: The values and institutions of Canada and the United States. Ottawa, ON: C.D. Howe Institute.

Liu, X., Lindquist, E., \& Vedlitz, A. (2011). Explaining media and congressional attention to global climate change, 1969-2005: An empirical test of agenda-setting theory. Political Research Quarterly, 64(2), 405-419.

Malka, A., Krosnick, J. A., \& Langer, G. (2009). The association of knowledge with concern about global warming: Trusted information sources shape public thinking. Risk Analysis, 29(5), 633-647.

Mankiw, G. N. (2007). One answer to global warming: A new tax. New York Times, September 19.

McCright, A. M., \& Dunlap, R. E. (2011). Cool dudes: The denial of climate change among conservative white males in the United States. Global Environmental Change, 21(4), 1163-1172.

Nevitte, N. (1996). The Decline of deference: Canadian value change in cross-national perspective. Peterborough, ON: Broadview Press.

Nisbet, M. C., \& Myers, T. (2007). The poll-trends: Twenty years of public opinion about global warming. Public Opinion Quarterly, 71(3), 444-470.

Organization for Economic Cooperation and Development (OECD). (2001). Environmentally elated taxes in OECD countries: Issues and strategies. Paris: OECD.

Organization for Economic Cooperation and Development (OECD). (2006). The political economy of environmentally related taxes. Paris: OECD.

Pal, L., \& Weaver, R. K. (Eds.) (2003). The government taketh away: The politics of pain in the United States and Canada. Washington, DC: Georgetown University Press.

Pew Research Center. (2009). Modest support for "cap and trade" policy: Fewer Americans see solid evidence of global warming. News Release. Washington, DC: Pew.

Pew Research Center. (2010). Public's priorities for 2010: Economy, jobs. Terrorism. News Release. Washington, DC: Pew.

Pralle, S., \& Boscarino, J. (2011). Framing trade-offs: The politics of nuclear power and wind energy in the age of global climate change. Review of Policy Research, 28(4), 323-346.

Prentice, J. (2009). Speaking points the Honourable Jim Prentice, to the Edmonton Chamber of Commerce. Environment Canada. Retrieved from http://www.ec.gc.ca/default.asp?lang=en\&n=6F2DE1CA1\&news=757C01543353-4BB4-B2F3-9E095A0DA33E

Rabe, B. G. (2007). Beyond Kyoto: Climate change policy in multilevel governance systems. Governance, 20(3), $423-444$.

Rabe, B. G. (2008). States on steroids: The intergovernmental odyssey of American climate change policy. Review of Policy Research, 25(2), 105-128.

Rabe, B. G. (2011). Contested federalism and American climate policy. Publius, 41(3), 494-521.

Rabe, B. G., \& Borick, C. (2012). Carbon taxation and policy labelling: Experience from American states and Canadian provinces. Review of Policy Research, 29(3), 359-383.

Rabe, B. G., Lachapelle, E., \& Houle, D. (2010). Climate compared: sub-federal dominance on a global issue. Unpublished manuscript currently under review in J. Wallner, L. Turgeon, M. Papillon, \& S. White (Eds.), Canada Compared. UBC Press.

Rivers, N. (2010). Current federal and provincial approaches to climate change mitigation: Are we repeating past mistakes? In J. C. Thomas \& J. R. Allan (Eds.), Canada: The state of the federation 2009: Carbon pricing and environmental federalism (pp. 45-60). Montreal: McGill-Queen's University Press.

Schuman, O., \& Presser, S. (1996). Questions and answers in attitude surveys: Experiments on question form, wording, and context. Thousand Oaks, CA: Sage.

Scruggs, L., \& Benegal, S. (in press). Declining public concern about climate change: Can we blame the great recession? To appear in Global Environmental Change.

Selin, H., \& VanDeveer, S. D. (Eds.) (2009). Changing climates in North American politics: Institutions, policymaking, and multilevel governance. Cambridge, MA: MIT Press. 
Simeon, R., \& Radin, B. (2010). Reflections on comparing federalisms: Canada and the United States. Publius, 40(3), 357-365.

Statistics Canada. (2011). Imports, exports and trade balance of goods on a balance-of-payments basis, by country or country grouping. Retrieved from http://www40.statcan.gc.ca/101/cst01/gblec02a-eng.htm

Stern, N. (2007). The economics of climate change: Stern review. New York: Cambridge University Press.

U.S. Census Bureau. (2011). U.S. trade in goods by country. http://www.census.gov/foreign-trade/statistics/country/ Wood, B. D., \& Vedlitz, A. (2007). Issue definition, information processing, and the politics of global warming. American Journal of Political Science, 51(3), 552-568.

Zia, A., \& Todd, A. M. (2010). Evaluating the effects of ideology on public understanding of climate change science: How to improve communication across ideological divides? Public Understanding of Science, 19(6), $743-761$. 